\title{
Ndonga Language
}

National Cancer Institute

\section{Source}

National Cancer Institute. Ndonga Language. NCI Thesaurus. Code C154048.

A Niger-Congo Bantu language spoken in Namibia and parts of Angola. 